\title{
Economic and Institutional Determinants of FDI in the Chilean Case: An Empirical Analysis, 1960-2014
}

\author{
Miguel D. Ramirez ${ }^{1, *}$ \\ ${ }^{1}$ Department of Economics, Trinity College, Hartford, CT, 06106, USA \\ *Correspondence: Department of Economics, Trinity College, Hartford, CT, 06106, USA. \\ E-mail: miguel.ramirez@ trincoll.edu
}

Received: June 22, 2017 Accepted: July 16, 2017 Published: August 25, 2017

doi: 10.5296/rae.v9i3.11435 URL: https://doi.org/10.5296/rae.v9i3.11435

\begin{abstract}
This paper examines some of the major economic and institutional factors underlying the surge in foreign direct investment (FDI) flows to Chile during the more recent 1990-2014 period. It reports econometric results which suggest that standard economic variables and major changes in the institutional-legal status of foreign capital are, in large measure, responsible for the rapid increase in net FDI inflows to leading sectors of the Chilean economy. Cointegration analysis and error-correction modeling suggest that market size, the real exchange rate, the debt-service ratio, education, physical infrastructure, and the Fraser Institute's economic freedom index are economically significant in explaining the variation in net FDI inflows to the country. Dummy variables, designed to capture qualitative factors such as the impact of economic crises and institutional reforms, are also included and they have their anticipated signs and are statistically significant. The paper also addresses the long-term negative effects of rapidly growing profit and dividend remittances on the financing of capital formation and the Chilean balance of payments in recent years.
\end{abstract}

J.E.L. Codes: C22, O10, O40, O57.

Keywords: Chilean economy; cointegration analysis; error correction model; Gross Capital Formation; FDI flows; Granger causality test; Johansen and Juselius test; remittances of profits and dividends; Schwartz Bayesian Criterion (SBC); Theil inequality coefficient; unit roots. 


\section{Introduction}

Beginning in the decade of the 1990s and continuing into the first two decades of the $21^{\text {st }}$ century, foreign direct investment (FDI) flows undertaken by transnational corporations (TNCs) have become one of the leading factors in promoting the process of economic globalization. Between 1990 and 1996 these flows averaged $\$ 254.3$ billion on an annual basis, while during the 1997-2014 period they averaged a staggering $\$ 1,130$ billion, or practically four and half time as much [see UNCTAD, 2003; and 2016]. The acceleration in FDI inflows during the 1990s and early 2000s was notable because an increasing proportion of these funds were directed to the developing nations, including the countries of Latin America and the Caribbean. From a relative standpoint, Latin America's share of FDI inflows to developing countries rose from 29 percent in 1995 to an-all time high of 39.5 percent in 2000, before falling to 28.3 percent during the recession year of 2009 , and then rebounding, respectively, to 30.5 and 33.7 percent in 2010 and 2011-12. The region's share fell again to 26.7 percent in 2013-14 following a significant decline in cross-border mergers and acquisitions in Central America, lower commodity prices which reduced investment in extractive industries, particularly in South America, and the completion of major privatizations in industry, banking, and mining (see UNCTAD, 2015, pp. 58-62).

The increase in net FDI flows channeled to these countries, particularly Chile, has been nothing short of spectacular when you factor in the relatively small size of Chile's economy. Between 1990 and 1996 Chile averaged net FDI inflows of $\$ 1.2$ billion, while during the 1996-2014 period it raised its average more than fourfold to $\$ 5.5$ billion (ECLAC, 2016, Table A1.10, p. 97; and UNCTAD, 2015). During the latter period, Chile's average ranked only behind Brazil ( $\$ 33.6$ billion), Mexico ( $\$ 15.3$ billion), and Argentina ( $\$ 6.8$ billion)Bmuch larger economies Bin its ability to attract net FDI inflows (ECLAC, 2007; 2016, Table A1.10, p. 97). The extant literature contends that, in large part, this has been due to Chile $=$ s relatively successful adoption and implementation of macroeconomic stabilization measures and market-based structural reform programs. The former have insured high and sustained rates of economic growth with relatively low inflation rates since 1985, while the latter have taken the form of privatization and debt conversion programs, the liberalization of the tradeable sector, and the removal of overly restrictive FDI legislation concerning the repatriation of profits as well as local content and export requirements. The adoption of these fiscally prudent and structural reform policies has reassured both foreign and domestic investors in the country's commitment to market-based, outward-oriented reforms (see Armendariz and Larrain, 2017, pp. 246-252; Edwards, 1999; Edwards and Lederman, 2002; and Irwin, 2015).

However, critics of the neoliberal model contend that the rapid and far-reaching liberalization of the tradeable sector was undertaken with little or no regard to its negative impact on domestic industry, employment, and the environment; moreover, they contend that the removal of restrictions on the remittances of profits and dividends has generated in recent years a growing reverse flow to parent companies which has become a significant constraint on the balance of payments (see Chang, 2008; Cypher, 2014, pp. 527-572; Ffrench-Davis, 1999; Green, 2013; and Weisbrot, 2015). Only time will tell if these reforms are sustainable in the long run, particularly in the wake of recent economic and financial crises that have 
buffeted the region. What is indisputable, however, is that FDI flows will not only play a strategic role in modernizing Chile's Band Latin America's-- economy, but in providing future income and employment opportunities.

In view of the above, this paper analyzes the recent evolution, rationale, and major economic and institutional determinants of FDI flows to Chile. Chile was one of the earliest countries in the region to adopt and implement market-based reforms, albeit at great social and political cost. The process of economic and financial liberalization began following the brutal military coup of 1973 and, in recent years, Chile has further liberalized its FDI regime by modifying Decree Law 600 and its debt capitalization mechanism (Chapter XIX of the Central Bank's Compensation of International Exchange Regulations). FDI flows in the Chilean case have, historically, been channeled to traditional sectors such as mining and energy sectors. However, with the return of democracy during the nineties, a significant proportion of these funds have been channeled to export-oriented manufacturing operations or to non-traditional sectors such as renewable energy (wind farms) and industrial machinery using innovative technological processes and managerial techniques (see Alatorre and Razo, 2010). An analysis of the evolution and determinants of FDI flows to Chile during the decade of the nineties and beyond should uncover important trends and provide valuable policy insights to government officials seeking to attract these flows to the country.

The layout of the paper is as follows: First, it reviews the extant literature on the major economic and institutional determinants of FDI. Second, the paper gives an overview of net FDI flows to Chile in terms of their absolute magnitude and relative contribution to the financing of private capital formation. Third, the paper presents cointegration and error-correction model results that identify some of the major economic and institutional determinants of FDI flows to Chile during the 1960-2014 period. The concluding section summarizes the major arguments and offers some policy prescriptions for attracting FDI into the region and enhancing its positive direct and indirect effects.

\section{Conceptual Framework}

From a theoretical standpoint, John Dunning $(1981$; 1988) has developed one of the most comprehensive explanations of why TNC firms undertake cross-border investments. He argues that TNCs invest abroad when three sets of relative advantages are present. First, the establishment of TNC subsidiaries gives the parent firms exclusive ownership rights over patents, trademarks, commercial secrets and production processes, thereby effectively denying access to both foreign and domestic competitors. Second, they generate for TNC affiliates locational advantages that arise from direct access to growing markets and lower unit labor costs, reduced transportation and communication costs, avoidance of tariffs and non-tariff barriers, and last but not least, direct access to raw materials, low-cost unskilled labor, and intermediate products that are indispensable for the production of certain goods. Michael Mortimore (2003), building on Dunning's work, argues that the relative importance of location specific determinants depends on TNC motivations for investing, viz., whether FDI is motivated by market-seeking (access to internal and export markets), natural 
resource-seeking (access to natural resources and low-cost labor) or efficiency-seeking reasons (cost and quality of human resources and physical infrastructure resources).

Third, Dunning points to the advantages TNCs derive from internalizing certain operations because utilizing market mechanisms are relatively more burdensome and costly. For instance, many TNCs would rather establish a subsidiary abroad and assume directly the contractual and administrative costs associated with research, development, production, and marketing of a given product or service, thereby avoiding the transaction costs associated with leasing licenses and securing patents to undertake production or hiring the services of advertizing agencies to market and distribute their products. In this connection, Markusen (1995) argues that firms choose direct investment rather than licensing primarily because of the non-excludability property of new knowledge capital; viz., it is too costly for TNCs to prevent licensees from Adefecting and copying the new technology at little cost and setting up their own domestic firms in direct competition with the TNCs (p. 182).

Host country determinants also seem to play a very important role in either attracting or discouraging FDI flows to developing countries. For example, countries that exhibit a greater degree of political and macroeconomic stability, the existence of well-defined and enforceable property rights when it comes to the transfer of technology, liberal legislation governing the remittance of profits and dividends, and limited or non-existent local content or export requirements tend, on average, to attract greater flows of FDI. However, from the standpoint of the host country, the very factors which act as an incentive for FDI flows in the short run may prove detrimental to long-term economic development if they lead to a net outflow of resources, few backward and forward linkages, and limited transfers of technology and managerial knowhow (see Blomstrom and Persson, 1983; Cypher, 2014; and Yeager, 1998).

The nature and scope of government policies are also a highly important factor in determining whether FDI flows to developing economies such as Chile. For example, FDI is likely to be attracted to countries where governments ensure an adequate provision of economic and social infrastructure in the form of paved roads, ports, airfields, relatively cheap energy supplies, and a well-educated and disciplined work force. In this connection, several investigators have found that the availability of skilled workers and adequate physical infrastructure are important determinants of FDI flows because it enables TNCs to strengthen both their ownership and locational advantages, thus allowing them to expand their market not only in the host country but the region as well (see Cypher, 2014; Ramasamy and Young, 2004). In addition, FDI flows are likely to be encouraged by government policies that lead to the establishment of a legal-institutional framework that is conducive to business activity; viz., one that significantly reduces the transactions costs associated with negotiating contracts, improves information about the quality of goods and services, and make sure that the parties to a formal agreement honor their commitments (see Yeager,1999).

Finally, changes in a country's exchange rate policy play a key role in altering its relative attractiveness to net FDI inflows. Not surprisingly, economists are not entirely of one mind when it comes to the optimal exchange rate strategy to pursue. For example, some 
investigators argue that a policy that keeps the real exchange rate undervalued relative to that of its key investment partners is, ceteris paribus, likely to enhance FDI flows because it artificially reduces the unit costs of the country's factors of production and thus enables investors to make a significantly larger investment in terms of the domestic currency. They also contend that it enhances the profitability of the export-oriented sector which, in turn, attracts FDI flows to them. Therefore, the amount of FDI should increase with a real devaluation of the domestic currency after a reasonable lag (see ECLAC, 1998; De Vita and Lawler, 2004).

Other researchers contend that a policy that leads to a real appreciation of the domestic currency is likely to encourage FDI inflows because it enhances the foreign currency (dollar) value of the remittances of profits and dividends back to the parent company (see Cypher, 2014; De Mello, Jr., 1997; and De Vita and Lawler, 2004). After all, it is the real rate of return on their initial (dollar) investment that matters to the parent company. In light of the conflicting views in the literature on the impact of the exchange rate on FDI flows, it is best, from a policy standpoint, to pursue a credible strategy that maintains the country's real exchange rate in line with that of its key trading and investment partners.

\section{FDI Flows to Chile}

The lost decade of the 1980s led to an absolute decrease in net FDI inflows to Latin America and the Caribbean during the first half of the 1980s, after which they began to increase steadily during the second half of the 1980s and posted a dramatic upward surge during the decades of the 1990s and 2000s. Net FDI flows to the countries of Latin America and the Caribbean rose dramatically from $\$ 8.4$ billion in 1990 to $\$ 77.2$ billion in 2000 and almost 100 billion in 2008 , before falling precipitously to $\$ 72.2$ billion in 2009 as a direct result of the adverse effects of the U.S. Great Recession of 2007-09 (see UNCTAD, 2015). However, in the wake of the dramatic commodity-induced economic recovery experienced by South America (particularly, Argentina, Brazil, Chile, and Peru) during the 2010-12 period, these net flows are estimated to have risen sharply to $\$ 153.5$ billion in 2011 and $\$ 149$ billion in 2012 (see ECLAC, 2016; and UNCTAD, 2016).

The strength and resilience of FDI flows is revealed by the fact that despite the serious economic and financial crises that have buffeted the region, including the ATequila crisis of 1994-95, the 1997-98 Asian crisis, the Argentinean economic collapse of 2001-02, and the U.S.'s Great Recession, they have, time and again, managed to stage a remarkable recovery, particularly after 2002. In absolute terms, the major recipients of FDI flows have been concentrated in a few major countries of the region, in order of importance of the cumulative level of net inflows during the 2000-2012 period, they are Brazil, Mexico, Chile, Argentina, Colombia, Peru, and Venezuela. The major supplier of FDI flows to Latin America during the decades of the 1990s and 2000s (and historically) has been the United States followed, in order of importance, by Great Britain, Japan, China, Germany, and France (see ECLAC, 2016). 


\section{Ml Macrothink}

In relative terms, Figure 1 below shows net FDI flows as a percentage of GDP for Chile and Mexico during the 2002-2014 period. The figure reveals that during the decade of the 2000s and beyond, both Chile and Mexico exhibited a strong record of attracting net FDI inflows, and with the exception of 2012 for Mexico, never falling below 1.0 percent of their countries' respective GDPs. More remarkably, in the case of Chile there is only one year when the ratio falls below 2 percent, viz., 2010; in fact, for the entire 13-year period, FDI inflows averaged a remarkable 3.7 percent for Chile, and a respectable 1.8 percent in the case of Mexico. FDI flows in the case of Chile have been primarily, but not exclusively, attracted to extractive and natural resource-based industries such as mining, fishing, and agriculture, while in the case of Mexico, the manufacturing and financial services sectors have been the major destinations of these flows.

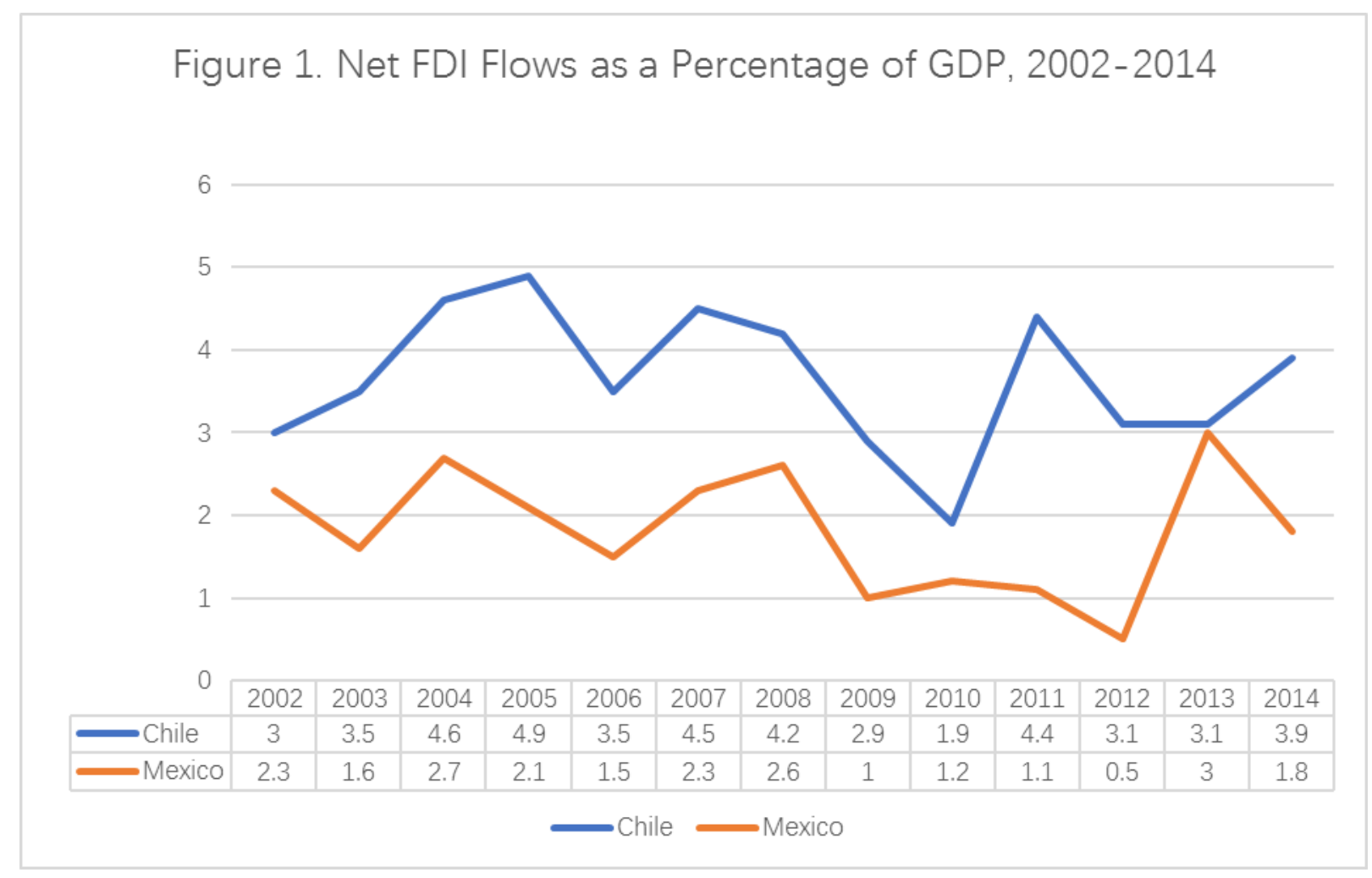

Figure 1. Net FDI Flows as a Percentage of GDP, 2002-2014

Source: ECLAC (2016).

The importance of these net inflows is more fully appreciated by focusing on their evolution relative to these countries' gross fixed capital formation, since they are viewed as a source of investable resources to the host nation. Figure 2 below shows that throughout the decade of the 2000s, and particularly after 2003, FDI flows represented more than 15 percent of Latin America's gross fixed capital formation (GFCF); and in the case of Chile, these flows averaged more than a quarter of gross fixed capital formation during the 2003-2011 period--the highest figure among the major countries of the region, or for that matter, the developing world.(Note 1) 
Figure 2. Net FDI Flows as a Percentage of GFCF, 2002-

2014

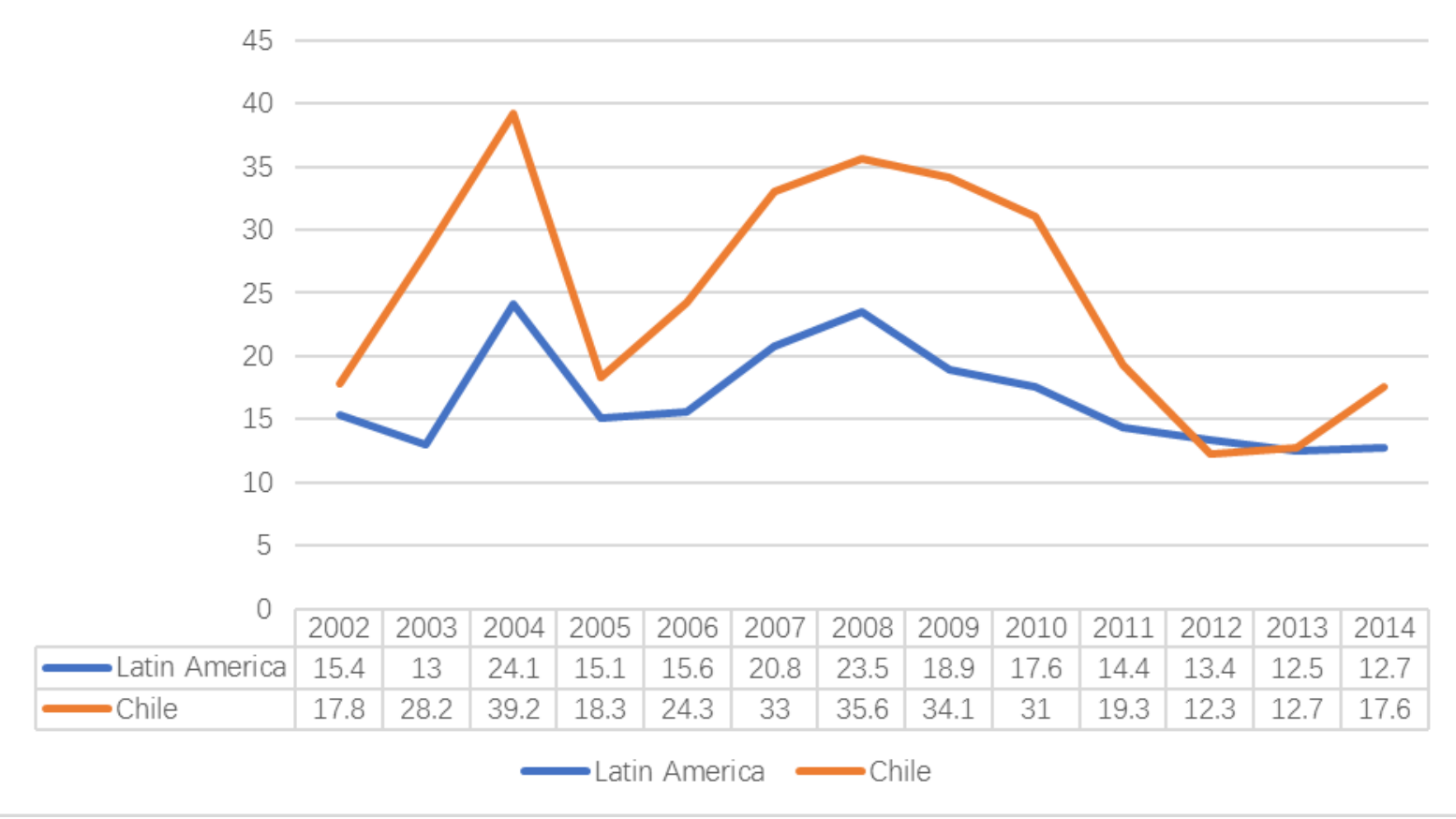

Figure 2. Net FDI Flows as a Percentage of GFCF, 2002-2014

Source: ECLAC (2016).

Critics of FDI , however, contend that instead of increasing the investable resources of the host nation, FDI flows divert resources away from capital formation because they generate a substantial reverse flows in the form of remittances of profits and interest to the parent companies, as well as through the widespread practice of intra-firm transfer pricing (see Chang, 2008; Cypher and Dietz, 2003; Cypher, 2014; Figueroa, 1998; Plasschaert, 1994; and Ram and Zhang, 2002). In their view, in order to assess the net contribution of FDI to the financing of private capital formation, one must first deduct from gross FDI inflows the repatriation of profits and interest to the parent companies, often residing in the U.S. for many of the countries in question.

Partial support for this contention can be surmised from the following figures: profit and interest remittances by Latin America and the Caribbean to the developed countries more than quadrupled between 2004 and 2012, from $\$ 33.6$ billion to $\$ 158$ billion (see ECLAC, 2012, Table 2.2.1.1, p. 97; and ECLAC, 2016, Table A1.1, p. 88). To put these figures in perspective, in 2004 and 2012, net FDI inflows to the region were respectively $\$ 50.8$ and $\$ 148.5$ billion; that is, reverse outflows in the form of profits and interest from Latin America and the Caribbean to the developed countries grew from an already high 66 percent of net FDI inflows in 2004 to over 100 percent (106.4 to be exact) in 2012! That is, during the year 2012 the outflow of resources (in the form of profits and interest) from the region exceeded 


\section{Al Macrothink}

the inflow in the form of net FDI by practically $\$ 10$ billion. Insofar as Chile is concerned, given its highly liberal policies towards the repatriation of profits, it experienced a large outflow of net profits during the decade of the 2000s and beyond; Figure 3 below reveals that for the 2002-2014 period, the repatriation of net profits on FDI rose from $\$ 2.1$ billion in 2002 to $\$ 10.3$ billion in 2005 and a staggering $\$ 20$ billion in 2007 , and thereafter fell to $\$ 11$ and $\$ 8.8$ billion in 2013 and 2014, respectively. To put these figures in perspective, the outflow of net profits in 2014 alone represented 41.3 percent of the gross inflows of FDI into the country that year, and almost as much as the net inflow of FDI which stood at $\$ 9.4$ billion (ECLAC, 2016, p. 97; and UNCTAD, 2016)! In fact, relative to the country's gross inflows of FDI, Chile's repatriation of net profits on FDI during the 2002-2014 period averaged 77 percent (computed from ECLAC, 2015; and UNCTAD, 2016). If we were to subtract these profits from gross FDI inflows on a yearly basis, and then express the figure as a proportion of fixed capital formation, it would be evident that the net contribution of FDI to the financing of gross fixed capital formation in Chile, although increasing in recent years, would be far less than that advertised by the unadjusted figures in Figure 2 above.

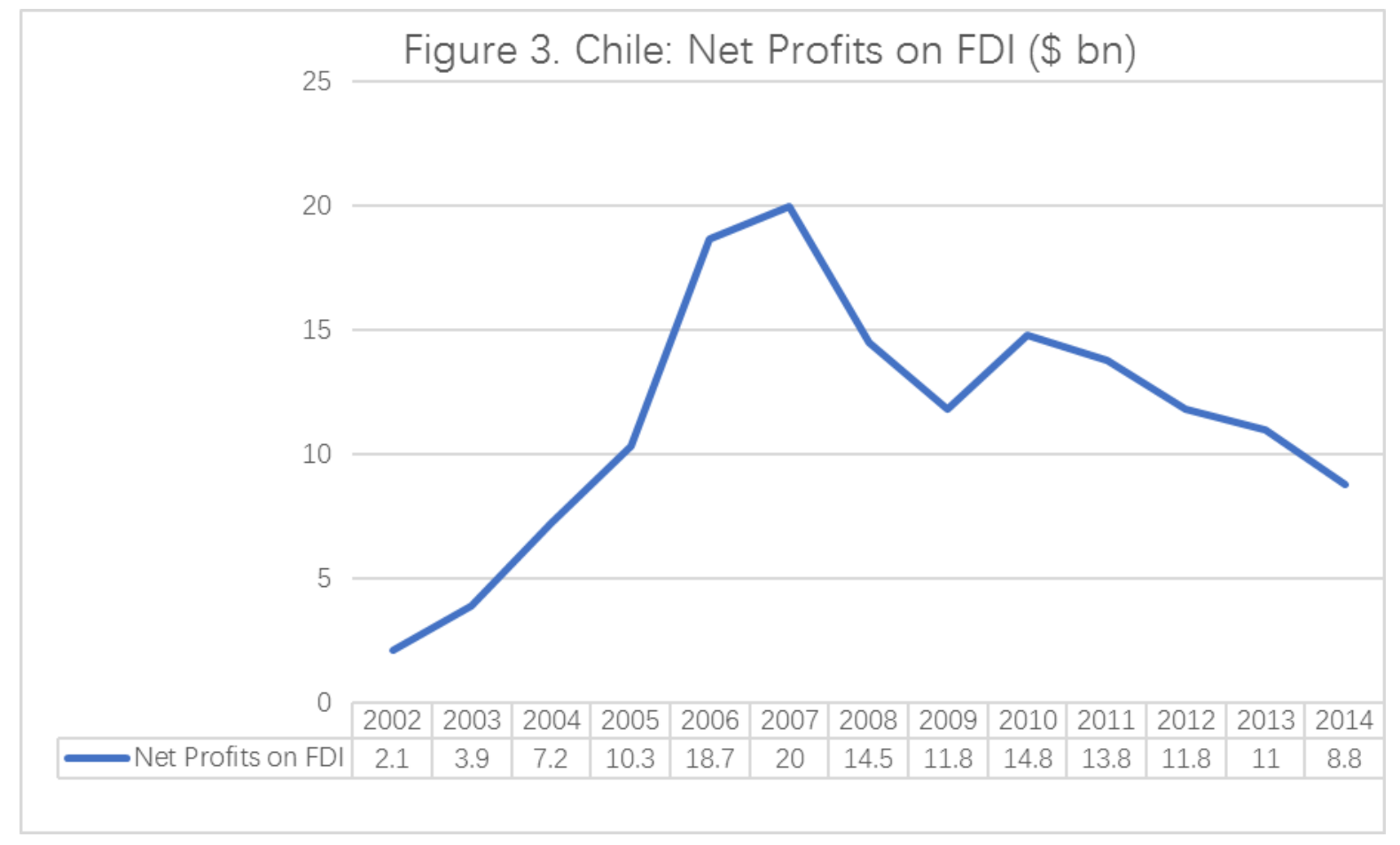

Figure 3. Chile: Net Profits on FDI ( $\$$ bn)

Source: ECLAC (2016); and UNCTAD (2016).

Economic theory, however, suggests that rather than focus on the flows of FDI to the countries of Latin America, it is theoretically more appropriate to concentrate on the accumulated stock of FDI, because increases in the latter raise the host country's marginal productivity of private capital (and labor), a process that eventually translates into higher 
levels of output, employment creation, and potential tax revenues [see Bosworth and Collins, 1999]. The stock of FDI in Latin America (1990 dollars) rose from $\$ 175.6$ billion in 1990 to $\$ 355.4$ billion in 2000, and an impressive \$1,146.6 billion in 2010 (see ECLAC, 2007; and UNCTAD, 2016, Annex Table 2). Just between 2000 and 2010, Latin America's stock of FDI more than tripled - a cumulative increase which is greater than that of the entire Alost decade of the 1980s and the first half of the 1990s! In this connection, Chile's performance mirrored and excelled that of the region, in view of the relatively small size of its economy compared to Brazil and Mexico - the major recipients of FDI flows in the region. Chile's stock of net FDI rose from $\$ 34.5$ billion in 2000 to a level of $\$ 103.4$ billion in 2010, or about three times (obtained from UNCTAD, 2016, Annex Table 2). From a relative standpoint, the rise of Chile's stock of inward FDI is even more impressive, increasing from 58.8 percent of GDP in 2000 to 72 percent of GDP in 2010--by far, the highest share of any major country of the region, including Argentina, Brazil, Colombia, Mexico, Peru, and Venezuela (see ECLAC, 2007; and UNCTAD, 2016). In addition to the direct effects associated with a greater stock of FDI, several investigators argue that there are indirect positive spillover effects on overall efficiency that arise from enhanced competition generated by foreign firms, the transfer of needed technology and managerial knowhow to local firms, and trade-induced learning-by-doing effects as local firms attempt to overcome competition in the global market (see Armedariz and Larrain, 2017; Cypher, 2014; De Mello Jr., 1997; Ram \& Zhang, 2002; and Vadlamannati and Tamazian, 2009).

\section{Empirical Model and Results}

Historically, empirical work on the determinants of FDI flows to Latin America and the Caribbean have been relatively few given the paucity and inconsistency of the data, as well as the economic and institutional heterogeneity present in these countries. However, in recent years, a number of studies focusing on the determinants (and impact) of FDI flows to several countries of the region have arisen as a result of the renewed surge in net flows to these countries beginning in the second half of the 1980s and the availability of reliable and methodologically consistent time series data for a number of countries (see Armedariz and Larrain, 2017; Agosin, 1995 and 1999; Bloomstrom and Wolff, 1994; DeMello, Jr., 1997; ECLAC, 1998 and 2000; Figueroa, 1998; Ramasamy and Yeung, 2004; Ramirez, 2000; Ros, 1994; and Zhang, 2001).

\subsection{Model}

Following the lead of Agosin (1995), (Ramasamy and Yeung, 2004), Ros (1994) and Zhang (2001), this study estimated a foreign direct investment (FDI) function of the following general form:

$$
\mathrm{FDI}_{\mathrm{t}}=\mathrm{f}\left(\mathrm{GDP}_{\mathrm{t}-\mathrm{i}}, \operatorname{REX}_{\mathrm{t}-\mathrm{i}}, \mathrm{DS}_{\mathrm{t}-\mathrm{i}}, \mathrm{SED}_{\mathrm{t}-\mathrm{i}}, \mathrm{PAVED}_{\mathrm{t}-\mathrm{i}} ; \mathrm{EFI}_{\mathrm{t}-\mathrm{i}}, \mathrm{D}_{\mathrm{i}}\right)+\varepsilon_{\mathrm{t}}
$$

It includes standard arguments such as real GDP, the real exchange rate (REX), the ratio of debt service payments to exports of goods and services (DS), the number of students enrolled in secondary education (SED) as a proxy for human capital, the total kilometers or the 
percentage of paved roads as a proxy for physical infrastructure, the economic freedom index (EFI) generated by the Fraser Institute, and dummy variables $\left(\mathrm{D}_{i}\right)$ to explain the variation in FDI flows to Chile during the $1960-2014$ period. (Note 2) $\varepsilon_{t}$ is a normally distributed error term.

Chile's potential market size is proxied by the lagged value of real GDP because foreign investors make their investment decisions based on expectations generated, in part, by what the level of real GDP was in the preceding year. The sign associated with this variable is expected to be positive. Market size was also proxied by the value of real exports (X) in view of the growing importance of external markets for the Chilean economy since 1987 (results available upon request). For example, the data indicate that after 1987 a significant share of the country's GDP (at least 25 percent) has been destined for export markets in the high income OECD (Europe, U.S. and Japan) countries and China (see OECD, 2003, Table A.1).

The real exchange rate is included in the model because it is the most important link between economic policy and international competitiveness and, as explained in Section II, it is expected to have an indeterminate sign in the Chilean case. (Note 3) On the one hand, a considerable proportion of FDI flows to Chile, in recent years, are concentrated in foreign affiliates which have a strong export orientation, such as cellulose and paper, telecommunications, and manufacturing. A ceteris paribus real depreciation of the domestic currency (a rise in REX) should increase the profitability of these sectors and, ceteris paribus, induce FDI flows to them. On the other hand, a real depreciation of the domestic currency reduces the (dollar) value of the remittances of profits and dividends back to the parent company, thereby reducing the real rate of return on the parent company's initial (dollar) investment. According to this rationale, a ceteris paribus depreciation of the domestic currency should reduce FDI flows to the country. This variable is introduced with a lag because the decision to invest in new plant, machinery, and equipment in a foreign country takes time due to recognition, implementation, and institutional-legal delays.

The debt service payments- to- exports ratio, was included to measure country risk; viz., the higher the ratio, the greater the probability that a BOP crisis will emerge which may lead to the imposition of restrictions on profit and dividend remittances, thereby depressing FDI flows to the country. This variable is also designed to capture the influence of external factors on the Chilean economy, such as the increase in the cost of credit and/or demand for the country's exports. It is anticipated to have a negative and statistically significant effect on inward FDI flows.

The final quantitative variables, the number of students enrolled in secondary education (thousands) and the kilometers of paved roads (hundreds), were included, respectively, as crude proxies for the quality of the country's human and physical capital. Insofar as the education variable is concerned, it would have been preferable to have used the secondary enrollment ratio, but this variable was not available for the entire period. In the case of the physical infrastructure variable, the percentage of paved roads was also utilized and, as reported below, the results were not significantly different. The rationale for including these variables is relatively straightforward. For example, it is hypothesized that, ceteris paribus, 
the higher the level of education in the country, the more attractive it is to foreign investors both from a cost standpoint (lower unit labor costs) and a demand-side perspective (greater purchasing power and more informed consumers). In the case of physical infrastructure, it is hypothesized that the higher the percentage of paved roads in the country, the more attractive it is to TNCs because it allows them to move resources and distribute goods at lower cost (see Ramasamy and Yeung, 2004).

Turning to the qualitative variables, the economic freedom index generated by the Fraser Institute for Chile was included in the estimation for the 1980-2014 period due to unavailability of data before 1980. The general idea is that countries with greater economic freedom have a legal-institutional framework that is more conducive to business activity and economic growth than countries that adopt policies that restrict "economic freedom." This index is a summary measure of a number components of "economic freedom" such as monetary policy and price stability, the top marginal tax rate, legal structure and property rights, viability of contracts, and the rule of law. The index has a scale that ranges from 1 to 10, where a score of 10 represents the highest attainable level of economic freedom. (Note 4) It is anticipated that this variable will have a positive and statistically significant effect on inward FDI flows to the region. It should be noted that all of the countries in this study report indices that range between 2 and 8, with Chile and Costa Rica at the high end and Ecuador and Peru at the low end.

Dummy variable $\mathrm{D}_{1}$ equals 1 for the economic crises years of 1970-1973 (administration of president Salvador Allende Gossens and 1973 military coup), onset and aftermath of debt crisis in 1982-83, and the downturn in economic activity induced by the 2008-09 Great Recession; it is 0 otherwise; this variable is anticipated to have a negative and statistically significant effect on foreign (and domestic) investment because of the uncertainty generated for expected returns from political turmoil and depressed economic activity. Again, these events may induce government officials to adopt a more nationalistic stance and impose restrictions on foreign investors in terms of the sectoral destination of FDI flows and the repatriation of profits and dividends. $\mathrm{D}_{2}$ is set equal to 1 for the 1987-97 period (acceleration of real economic growth associated with the Chilean government's decision to pursue vigorously an outward-oriented strategy of economic development beginning in 1986-87. $\mathrm{D}_{3}$ equals 1 for the debt-led growth years of 1978-81. Both $\mathrm{D}_{2}$ and $\mathrm{D}_{3}$ are expected to have positive and statistically significant coefficients. The model was also estimated with dummy variable $\mathrm{D}_{2}$ multiplied by real GDP. By estimating this variable interactively with real GDP one can assess whether the consolidation of market-oriented reforms had a positive and significant effect on the capacity of market size to affect real FDI flows.

\subsection{Data}

Economic data (including foreign direct investment) used in this study were obtained from official government sources such as the Instituto Nacional de Estadisticas (various issues), the Banco Central de Chile's Memoria Anual (various issues) and the Banco's comprehensive longitudinal publication entitled, Indicadores Economicos y Sociales, 1960-2001 [see August 2003 Excel edition]; and ECLAC, Statistical Yearbook for Latin America and the Caribbean 
(2016). data was also obtained from UNCTAD, World Investment Report 2015-16. (Note 5)

The FDI stock variable (KDI) in millions of 1977 pesos was generated using a standard perpetual inventory model. Initial stocks of private foreign capital were estimated by aggregating over four years of gross investment (1957-1960), assuming an estimate of the rate of depreciation of 5 percent. (Note 5) GDP is real gross domestic product in millions 1977 pesos. REX is the real exchange rate $(1978=100)$, where an increase represents a real depreciation of the domestic currency. DS is the ratio of debt-service payments- to- exports of goods and services variable; debt-service payments include both amortization (gradual payment of principal) and interest payments on the country's total external public debt. SED refers to the number of students matriculated in secondary education, and PAVED is defined as the total number of paved roads (in kilometers).

\subsection{Cointegration Analysis}

Unit root tests were undertaken for the variables in question given that it is well-known that macro time series data tend to exhibit a deterministic and/or stochastic trend that renders them non-stationary; i.e., the variables have means, variances, and covariances that are not time invariant (see Dickey and Fuller, 1979). Engle and Granger (1987) have shown that the direct application of OLS or GLS to non-stationary data produces regressions that are mispecified or spurious in nature. Table 1 below presents the results of running an Augmented Dickey-Fuller test (one lag) for the log of the variables in both level and differenced form under the assumption of a stochastic trend. (Note 6) It can be seen that the variables in level form are non-stationary. In the case of first differences, however, the null hypothesis of non-stationarity (unit root) can be rejected for the relevant variables at least at the five percent level.

Table 1. Chile: Unit Root Tests for Stationarity, Sample Period 1960-2014

\begin{tabular}{lllll}
\hline Variables & Levels & First Difference & $\mathbf{5 \%}$ Critical Value $^{\text {a }}$ & 1\% Critical Value $^{\text {1\% }}$ \\
\hline LKDI & -0.13 & $-3.15 *$ & -2.92 & -3.56 \\
LGDP & 0.25 & $-6.52 * *$ & -2.92 & -3.56 \\
LREX & -2.43 & $-3.52^{* *}$ & -2.92 & -3.56 \\
LX & 0.34 & $-7.20^{* *}$ & -2.92 & -3.56 \\
LDS & -2.24 & $-7.98^{* *}$ & -2.92 & -3.56 \\
LSED & -1.66 & $-7.85 * *$ & -2.92 & -3.56 \\
LPAVED & 1.66 & $-5.07 * *$ & -2.92 & -3.56 \\
LRPAVED & -2.47 & $-4.51 * *$ & -2.92 & -3.56 \\
\hline
\end{tabular}

${ }^{a}$ Total number of observations is 55 which exceeds critical threshold of 50. Mackinnon critical values for rejection of null hypothesis of a unit root under the assumption of a stochastic trend.*Denotes significance at the 5 percent level; **denotes significance at the 1 percent level. Estimations undertaken with Eviews 9.5.

In view of the above, it is necessary to determine whether there is at least one linear combination of these non-stationary variables (in level form) that is I(0). In words, does there exist a stable and non-spurious (cointegrated) relationship among the relevant variables over 
the period in question? The Johansen and Juselius (1990) test was used to determine whether there is a stable long-run relationship among the relevant variables in logarithmic form, viz., the natural log of the stock of FDI (LKDI), the log of real GDP ( LGDP), the log of the debt service-to-GDP ratio (LDS), the log of the real exchange rate (LREX), the log of the number of students enrolled in secondary education (LSED), and the log of total paved roads (LPAVED). Application of the likelihood ratio (L.R.) test showed that the null hypothesis of no cointegrating relationship can be rejected at the 5 percent level (trace statistic $=72.69$ > critical value $=69.82$ (p-value: 0.029); and Max-Eigen statistic $=44.96>$ critical value $=$ 40.07 (p-value: 0.013 ), thereby suggesting that there is at least one unique linear combination of these non-stationary variables (in level form) that is stationary.

The cointegrating regression (normalized on LKDI) is given below.

\begin{tabular}{lllllll}
\hline \multicolumn{2}{l}{ Cointegrating Equation: } & \multicolumn{2}{l}{ Log likelihood } & 333.14 & & \\
\multicolumn{7}{l}{ Normalized cointegrating coefficients: } \\
\hline LKDI & LGDP & LREX & LDS & LSED & LPAVED & C \\
1.000 & -1.486 & 0.083 & 0.258 & -1.98 & -0.60 & 42.72 \\
& $(0.456)$ & $(0.033)$ & $(0.136)$ & $(0.375)$ & $(0.320)$ & \\
& {$[\mathrm{t}=3.259]$} & {$[\mathrm{t}=2.520]$} & {$[\mathrm{t}=1.897]$} & {$[\mathrm{t}=5.280]$} & {$[\mathrm{t}=1.890]$} & \\
\hline
\end{tabular}

Note: Standard errors are in parenthesis.

The signs are reversed because of the normalization process and they clearly show that, in the long run, LGDP, LSED, and LPAVED have a positive and significant effect on the stock of FDI (LKDI), while LREX and LDS have a negative and statistically significant effect. The relatively high log likelihood statistic suggests that the included variables taken together are highly significant in explaining the variation in the stock of FDI in the long run. It should be noted that the null hypothesis of no cointegration was also rejected at the 5 percent level when the log of real exports (LX) rather than LGDP was used to proxy market size (at least one cointegrating vector was present) (available upon request).

\subsection{Results}

The information provided by the L.R. test was also used to generate a set of error correction (EC) models that capture both the short and long-run behavior of the FDI relationship. For simplicity, consider below the basic EC model without EFI and the dummy variables:

$$
\begin{aligned}
\Delta \mathrm{LKDI}_{\mathrm{t}}=\alpha & +\beta_{1} \Delta \mathrm{LGDP}_{\mathrm{t}-\mathrm{i}}+\beta_{2} \Delta \mathrm{LREX}_{\mathrm{t}-\mathrm{i}}+\beta_{3} \Delta \mathrm{LDS}_{\mathrm{t}-\mathrm{i}}+\beta_{4} \Delta \mathrm{LSED}_{\mathrm{t}-\mathrm{i}}+\beta_{5} \Delta \mathrm{LPAVED}_{\mathrm{t}-\mathrm{i}} \\
& +\delta \mathrm{ECT}_{\mathrm{t}-1}+\varepsilon_{\mathrm{t}}
\end{aligned}
$$

The coefficients $(\beta=\mathrm{s})$ of the variables represent short-run percentage growth rates, while the coefficient, $\delta(<0)$, on the lagged EC term obtained from the cointegrating equation in level form denotes the speed of adjustment back to the long-run situation in which the variables grow at the same constant rate. $\varepsilon_{t}$ refers to the population disturbances which are (each) assumed to be normally independently distributed. To conserve space, the results of five of 
the EC models estimated in this study are given in Table 2 below. T-ratios are in parenthesis and one and two asterisks denotes, respectively, statistical significance at the 10 percent and 5 percent (or less) levels.

Table 2. Chile: Error-Correction Models, 1960-2014 $\left(\right.$ dependent variable $\left.=\Delta \mathrm{LKDI}_{\mathrm{t}}\right)$

\begin{tabular}{|c|c|c|c|c|c|}
\hline Variables & Equation (1) & Equation (2) & Equation (3) & Equation (4) & Equation (5) \\
\hline \multirow[t]{2}{*}{ Constant } & 0.09 & 0.07 & 0.08 & -0.46 & 0.09 \\
\hline & $(3.78)^{* *}$ & $(6.01)^{* *}$ & $(4.03)^{* *}$ & $(-1.47)^{*}$ & $(3.20) * *$ \\
\hline \multirow[t]{2}{*}{$\Delta \mathrm{LGDP}_{\mathrm{t}-2}$} & 0.30 & 0.34 & 0.39 & 0.61 & 0.29 \\
\hline & $(2.71)^{* *}$ & $(3.03)^{* *}$ & $(5.39)^{* *}$ & $(3.25)^{* *}$ & $(2.62)^{* *}$ \\
\hline \multirow{2}{*}{$\mathrm{D}_{2} * \Delta \mathrm{LGDP}_{\mathrm{t}-2}$} & ---- & ---- & 0.80 & ---- & ---- \\
\hline & & & $(1.99)^{* *}$ & & \\
\hline \multirow[t]{2}{*}{$\mathrm{EFI}_{\mathrm{t}-1}$} & ---- & ---- & ---- & 0.05 & ---- \\
\hline & & & & $(1.93)^{* *}$ & \\
\hline \multirow[t]{2}{*}{$\Delta \mathrm{LREX}_{\mathrm{t}-1}$} & -0.06 & -0.06 & -0.05 & -0.11 & -0.06 \\
\hline & $(-2.30)^{* *}$ & $(-3.22)^{* *}$ & $(-2.73)^{* *}$ & $(-1.70)^{* *}$ & $(-2.24)^{* *}$ \\
\hline \multirow[t]{2}{*}{$\Delta \mathrm{LDS}_{\mathrm{t}-2}$} & -0.05 & -0.07 & -0.06 & -0.11 & -0.04 \\
\hline & $(-2.86)^{* *}$ & $(-3.95)^{* *}$ & $(-3.83)^{* *}$ & $(-3.72)^{* *}$ & $(-2.29)^{* *}$ \\
\hline \multirow[t]{2}{*}{$\Delta \mathrm{LSED}_{\mathrm{t}}$} & 0.09 & 0.07 & 0.08 & 0.76 & 0.09 \\
\hline & $(4.99)^{* *}$ & $(3.74)^{* *}$ & $(5.34)^{* *}$ & $(2.90)^{* *}$ & $(4.57)^{* *}$ \\
\hline \multirow[t]{2}{*}{$\Delta$ LPAVD $_{\mathrm{t}-1}$} & 0.29 & 0.48 & 0.37 & ---- & 0.35 \\
\hline & $(2.11)^{* *}$ & $(2.57)^{* *}$ & $(2.44)^{* *}$ & & $(2.24)^{* *}$ \\
\hline \multirow[t]{2}{*}{$\mathrm{ECT}_{\mathrm{t}-1}$} & -0.13 & -0.11 & -0.11 & -0.26 & -0.13 \\
\hline & $(-3.64) * *$ & $(-3.39) * *$ & $(-3.86) * *$ & $(-2.86)^{* *}$ & $(-3.55) * *$ \\
\hline \multirow[t]{2}{*}{$\mathrm{D}_{1}$} & -0.04 & -0.06 & -0.06 & -0.05 & ---- \\
\hline & $(-3.44)^{* *}$ & $(-2.54)^{* *}$ & $(-3.32)^{* *}$ & $(-2.25)^{* *}$ & \\
\hline \multirow[t]{2}{*}{$\mathrm{D}_{2}$} & ---- & 0.12 & ---- & ---- & ---- \\
\hline & & $(3.66)^{* *}$ & & & \\
\hline \multirow[t]{2}{*}{$\mathrm{D}_{3}$} & ---- & 0.11 & 0.11 & ---- & ---- \\
\hline & & $(7.11)^{* *}$ & $(5.07)^{* *}$ & & \\
\hline $\operatorname{Adj} . R^{2}$ & 0.69 & 0.80 & 0.75 & 0.71 & 0.65 \\
\hline D.W. & 2.01 & 1.96 & 1.98 & 2.06 & 2.04 \\
\hline F-stat & $9.72 * *$ & $14.06^{* *}$ & $10.42 * *$ & $6.22 * *$ & $10.0 * *$ \\
\hline AIC. & -2.79 & -3.17 & -2.94 & -2.85 & -2.73 \\
\hline SBC & -2.41 & -2.72 & -2.48 & -2.69 & -2.39 \\
\hline
\end{tabular}

t-ratios in parenthesis. *Significant at the $10 \%$ level; **significant at the $5 \%$ level. ECT= Error-Correction Term; AIC $=$ Akaike Information Criterion; SBC Schwartz Bayesian Criterion. N=55 observations, except for eq. (4) where $\mathrm{N}=35$

The EC estimates reported in equations (1)- (5) suggest that a two-year lagged percentage change in real GDP has a positive effect on FDI flows (growth rate in the stock of FDI) and a 
one-year lagged percentage change in the real exchange rate has a negative effect. For example, the estimates in eq. (1) suggest that a ceteris paribus 10 percent increase in the percentage growth rate in real GDP during the current period generates a 3 percent increase in FDI flows to the country within two years, while a 10 percent rise in the growth rate in the real exchange rate (a depreciation) during the current period generates a 0.6 percent reduction in FDI flows in the following year. As anticipated, the ratio of debt service payments-to-exports variable had a negative and statistically significant effect on FDI flows when lagged 2 periods, while the education variable had a positive and significant effect. In the latter case, a 10 percent increase in the growth rate of secondary enrollment during the current period generates a 0.9 percent increase in FDI flows to the country. Finally, the relatively high and significant estimate for the physical infrastructure variable suggests that it is highly important in attracting FDI flows to the country. For example, in eq. (2), an increase in the percentage growth rate of paved roads by 10 percent generates, on average, a 4.8 percent increase in FDI flows to the country, ceteris paribus(Note 7)From an institutional standpoint, the results reported in eq. (2) suggest that the debt-led growth of the early 1980s (D3) and the liberalization of foreign investment rules during the 1987-97 (D2) period had a positive and statistically significant effect on FDI flows to Chile, while political and economic turmoil (D1) had a negative and statistically significant impact.

Although the real GDP variable is lagged in the reported EC models, it is possible that FDI flows may affect real GDP. To test for this possibility I ran a Pairwise Granger Causality Test with one and two lags. The results show that the null hypothesis that $\triangle$ LGDP does not AGranger cause $\triangle$ LKDI could be rejected at the 2 percent level for one lag (p-value: 0.0194 ) and at the 6 percent level with two lags ( $\mathrm{p}$-value $=.0602$ ), while the hypothesis that $\Delta$ LKDI does not AGranger cause $\triangle$ LGDP could not be rejected (p-value: 0.1968 for one lag, and for two lags=0.359). Of course, this test says nothing about Acausation per se; it only provides information about whether changes in one variable precede changes in another. (Note 8)

The ECM model was also estimated with dummy variable D2 multiplied by the change in the $\log$ of real GDP. By estimating this variable interactively with the change in the log of real GDP one can assess whether the consolidation of market-oriented reforms had a positive and significant effect on the capacity of market size to affect real FDI flows. The results are reported in eq. (3), and they suggest that the reforms enhanced further the positive impact of market size on FDI flows. Table 3 also reports results for the basic ECM model without the dummy variables to determine whether the quantitative variables maintain their signs and significance. As can be seen by eq. (5), the estimates are robust to the exclusion of the qualitative variables, and the EC term retains a relatively high degree of significance and explanatory power. Along the same lines, eq. (1) shows that the inclusion of qualitative variable D1 by itself does not alter the sign nor the significance of the quantitative variables in the EC model.

Eq. (4) reports estimates that include EFI as the relevant proxy for Chile $=$ s degree of "economic freedom" or the degree to which the legal-institutional framework of the country is conducive to business activity. The coefficient for the EFI variable suggests that it is positive and significant when lagged one period, viz., a 10 percent increase in the index 
during the current period generates a 0.5 percent increase in FDI flows to the country within one year, ceteris paribus. However, the estimates should be interpreted cautiously because the sample period had to be shortened to 35 years due to the unavailability of data for the EFI, and the LPAVED variable was excluded due to the high degree of collinearity with the EFI variable. (Note 9)

The Bruesch-Godfrey serial correlation LM test (with two lags) indicated that first order serial correlation was present in the reported EC models, so they were corrected by including an AR(1) term. The D.W. values for all equations in Table 2 suggest that the null hypothesis of no (positive) first order autocorrelation cannot be rejected at the 5 percent level. The relative fit and efficiency of the EC models is quite good for eqs. (1)-(3) and, as the theory predicts, the lagged residual terms in all eqs. are negative and statistically significant; e.g., the lagged EC term in eq. (1) suggests that a 10 percent deviation during the current period from long run FDI flows to Chile is corrected by about 1.3 percent in the next year on average. Finally, stability tests were conducted to determine whether the null hypothesis of no structural break could be rejected for key periods in Chile's history. The Chow breakpoint tests suggested that the null hypothesis could not be rejected for the crises years 1973 (F-stat: 1.373; p-value: 0.265), 1975 (F-stat: 1.63; p-value: 0.186), and 1982 (F-stat; 1.306; p-value: $0.291)$.

Before concluding, the EC models were used to track the historical data on the percentage growth rate in inward FDI flows to Chile during the period under review. Figure 4 below, corresponding to equation (2) in Table 2, shows that, on average, the model was able to track the turning points in the actual series relatively well. $\mathrm{D}(\mathrm{LKDI})$ refers to the actual series and $\mathrm{D}$ (LKDIF) denotes the in-sample forecast. In addition, Figure 5 below shows that the Theil inequality coefficient for this model is 0.156 , which is well below the threshold value of 0.3 , and suggests that the predictive power of the model is quite good (see Theil, 1966). The Theil coefficients can be decomposed into three major components: the bias, variance, and covariance terms. Ideally, the bias and variance components should equal zero, while the covariance proportion should equal one. The estimates reported in Figure 2 suggest that all of these ratios are close to their optimum values (bias $=0.00$, variance $=0.13$, and covariance $=$ 0.87). Sensitivity analysis on the coefficients also revealed that changes in the initial or ending period did not alter the predictive power of the selected models. 


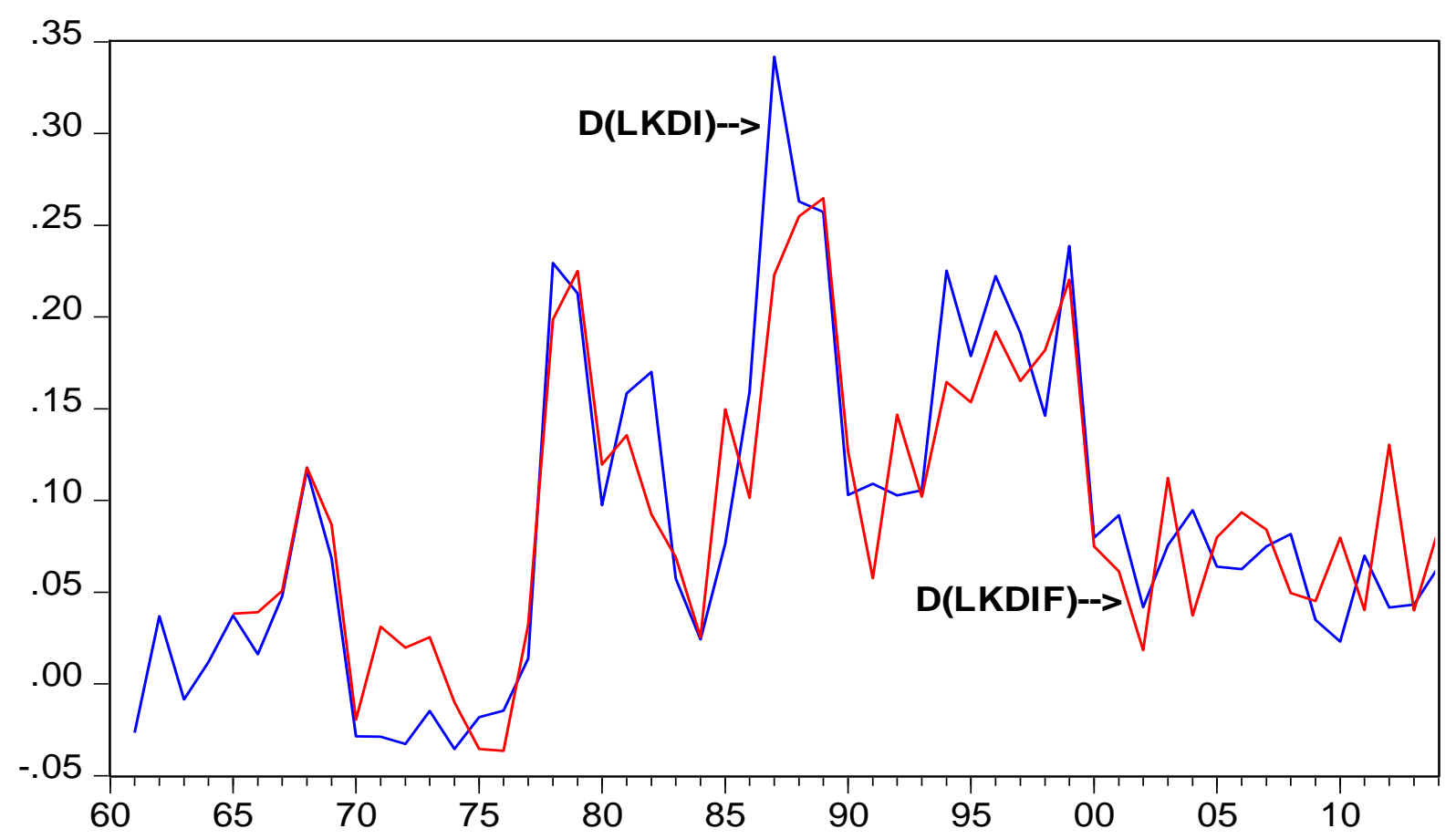

Figure 4. In-Sample Forecast, 1960-2014

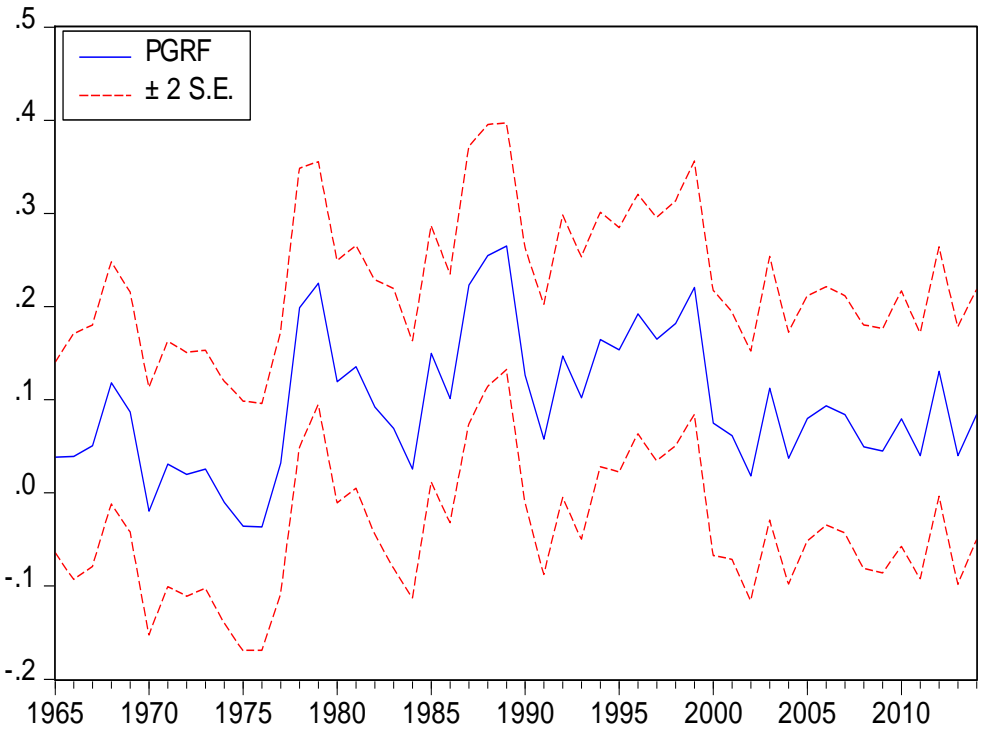

Figure 5. Theil Inequality Statistics, 1960-2014.

\begin{tabular}{|ll}
\hline Forecast: D(LKDIF) \\
Actual: D(LKDI) \\
Forecast sample: 19602014 \\
Adjusted sample: 19652014 \\
Included observations: 50 \\
Root Mean Squared Error & 0.038887 \\
Mean Absolute Error & 0.030084 \\
Mean Abs. Percent Error & 54.29478 \\
Theil Inequality Coefficient & 0.156203 \\
\multicolumn{1}{l}{ Bias Proportion } & 0.000000 \\
Variance Proportion & 0.131808 \\
Covariance Proportion & 0.868192 \\
Theil U2 Coefficient & 0.381507 \\
Symmetric MAPE & 46.35474
\end{tabular}

Forecast: $\mathrm{D}(\mathrm{LKDIF})$

Actual: $\mathrm{D}(\mathrm{LKDI})$

Included observations: 50

Root Mean Squared Error 0.038887

Mean Abs. Percent Error $\quad 54.29478$

Theil Inequality Coefficient 0.156203

Bias Proportion $\quad 0.000000$

Variance Proportion $\quad 0.131808$

Covariance Proportion

Theil U2 Coefficient $\quad 0.381507$

Figure 5. Theil Inequality Statistics, 1960-2014

\section{Conclusion}

Several major findings were presented in this paper. First, the evidence for Chile suggests that gross and net FDI flows have been substantial during the decade of the nineties and the first two decades of the $21^{\text {st }}$ century, particularly in relation to GDP and gross fixed domestic capital formation. However, once profit and dividend remittances are deducted from gross or 
net FDI inflows, the contribution of FDI to the financing of capital formation, although increasing in most years, is far less than advertised--and for some recent years, it has, in fact, diverted resources away from the financing of capital formation; that is, the outflow of profits has exceeded the net inflow of FDI.

Second, the econometric results suggest that market size (proxied by real GDP), the real exchange rate, the debt-service ratio, the human capital variable, and the physical infrastructure variable had their anticipated signs and were statistically and economically significant in explaining the variation of FDI flows to Chile over the 1960-2014 period. In addition the institutional variables, captured by the included dummy variables and the economic freedom index (EFI) reported by the Fraser Institute, had their expected effects and were statistically significant. In particular, the interactive dummy term suggests that institutional reforms have enhanced the effect of traditional variables such as real GDP in attracting FDI flows to the nation. The results for the EFI variable, however, should be interpreted with care given the paucity of the data for the index and its high degree of collinearity with some of the included regressors.

Third, the Johansen cointegration test indicated that there is a stable relationship among the relevant variables which keeps them in proportion to one another over the long run. This is a highly important contribution to the extant literature because previous econometric studies relating to Chile have failed to determine whether the estimated relationships were spurious or not. Finally, the EC models reported in Table 2 suggests that short-run deviations from the long-run FDI relationship are corrected in subsequent periods and, equally as important, Figure 4 shows that the in-sample forecasts of the EC models are able to track the turning points in the data relatively well.

From a research and policy standpoint, it would be highly important for future investigators to determine whether the massive inflows of FDI the country has received in recent years have been directed away from traditional (mining and agricultural) sectors and towards Agreenfield sectors (IT, renewable energy, and industrial machinery), where positive direct and indirect effects in the form of intangiblessuch as the transfer of technology and managerial knowhow are likely to be present. If econometric evidence shows that FDI inflows directed to these sectors have had a positive and economically significant effect on labor productivity growth, then it may help offset the short-term costs associated with generous subsidies, tax concessions, and pressures on the balance of payments as a result of the substantial growth in TNCs= remittances of profits and dividends from the country in recent years. The estimates also suggest that FDI flows will be attracted, on a long-term basis, to developing countries such as Chile provided that policy makers avoid sharp depreciations of the real exchange rate that lower the real (dollar) rate of return on FDI investments, and implement policies that ensure the availability of a well-educated citizenry, adequate physical infrastructure, and the rule of law. 


\section{Macrothink}

\section{References}

Agosin, M. R. (1999). Trade and Growth in Chile. Cepal Review, 68, 79-100.

Agosin, M. R., ed. (1995). Foreign Direct Investment in Latin America. Washington, D.C.: Inter-American Development Bank.

Alatorre, Jose E., \& Carlos Razo. (2010). Inward FDI and its Policy Context. Vale Columbia Center. New York: Columbia University.

Armendariz, Beatriz \& Felipe Larrain B. (2017). The Economics of Contemporary Latin America. Cambridge, Massachusetts: MIT Press.

Bloomstrom, M., \& E. Wolff. Multinational Corporations and Productivity Convergence in Mexico. (1994). In W. Baumol, R. Nelson, and E. Wolff(eds.), Convergence of Productivity: Cross-National Studies and Historical Evidence. Oxford: Oxford University Press.

Bouton, L., \& M. A. Sumlinski. (1999). Trends in Private Investment in Developing Nations: Statistics for 1970-98. Washington, D.C.: International Finance Corporation.

Chang, Ha-Joon, (2008). Bad Samaritans. New York: Bloomsbury Press.

Cypher, J. M., \& J. L. Dietz. (2003). The Process of Economic Development. Second Edition. New York: Routledge.

Cypher, J.M. (2014). The Process of Economic Development. Fourth Edition. New York: Routledge.

De Mello, Jr., \& Luiz R. (1997). AForeign Direct Investment in Developing Countries and Growth: A Selective Survey. Journal of Development Studies, 34(1), 1-34. https://doi.org/10.1080/00220389708422501

De Vita, Glauco \& K. Lawler. (2004). AForeign Direct Investment and its Determinants: A Look to the Past, A View to the Future.@ In Foreign Investment in Developing Nations, edited by H.S. Kehal. New York: Palgrave Macmillan, Ltd. https://doi.org/10.1057/9780230554412_2

Dickey, D., \& W. Fuller. (1979). ALikelihood Ratio Statistics for Autoregressive Time Series with a Unit Root. Econometrica, June, 1057-1072.

Dunning, J. H. (1981). International Production and the Multinational Enterprise, Allen \& Unwin, Publishers USA

Dunning, J. H. (1988). Explaining International Production, London: Harper \& Collins.

ECLAC. (1998). La Inversion Extranjera en America Latina y El Caribe. Santiago, Chile: United Nations.

ECLAC. (2007). Foreign Investment in Latin America and the Caribbean, 2006 Report. Santiago, Chile: United Nations. 


\section{Macrothink}

ECLAC. (2012). Preliminary Overview of the Economies of Latin America and the Caribbean, 2012 Report. Santiago, Chile: United Nations.

ECLAC. (2015). Preliminary Overview of the Economies of Latin America and the Caribbean, 2015 Report. Santiago, Chile: United Nations.

ECLAC. (2016). Statistical Yearbook of Latin America and the Caribbean, 2016 Report. Santiago, Chile: United Nations. https://doi.org/10.18356/e1d2d8de-en

Edwards, S. (1999). How Effective are Capital Controls? Journal of Economic Perspectives, 13(4), 65-84. https://doi.org/10.1257/jep.13.4.65

Edwards, S., \& D. Lederman. (2002). The Political Economy of Unilateral Trade Liberalization: The Case of Chile. In J. Bhagwati, ed., Going Alone: The Case for Relaxed Reciprocity in Freeing Trade. Cambridge: MIT Press.

Engle, R.F., \& C.W.J. Granger. (1987). Cointegration and Error Correction: Representation, Estimation, and Testing. Econometrica, 55, 251-76. https://doi.org/10.2307/1913236

Ffrench-Davis, R., \& M.R. Agosin. (1999). ACapital Flows in Chile: From the Tequila to the

Asian Crises. Journal of International Development, 11, 121-139. https://doi.org/10.1002/(SICI)1099-1328(199901/02)11:1\%3C121::AID-JID580\%3E3.0. $\mathrm{CO} ; 2-\mathrm{Z}$

Figueroa, Adolfo. (1998). Equity, Foreign Investment and International Competitiveness in Latin America. The Quarterly Review of Economics and Finance, Fall, 391-408. https://doi.org/10.1016/S1062-9769(99)80124-0

Green, D. (2013). Faces of Latin America. New York: Monthly Review Press.

Hoffman, A. A. (2000). The Economic Development of Latin America in the Twentieth Century. MA.: Northhampton.

Johansen, S., \& K. Juselius. (1990). AMaximum Likelihood Estimation and Inference on Cointegration with Applications to the Demand for Money. Oxford Bulletin of Economics and Statistics, 52(May), 169-210.

Markusen, J.R. (1995). The Boundaries of Multinational Enterprises and the Theory of International Trade. The Journal of Economic Perspectives, 9(Spring), 169-189. https://doi.org/10.1257/jep.9.2.169

Mortimore, M. (2003). The Impact of TNC Strategies on Development in Latin America and the Caribbean, Published for Overseas Development Institute (UK), 1-23.

OECD. (2003). Economic Surveys: Chile. Paris: OECD.

Plasschaert, S. ed. (1994). Transnational Corporations: Transfer Pricing and Taxation. London Routledge.

Ram, R., \& Zhang, K.H. (2002). Foreign Direct Investment and Economic Growth: Evidence from Cross-Country Data for the 1990s, Economic Development and Cultural Change, 
51, 205-215. https://doi.org/10.1086/345453

Ramasamy B., \& Yeung, M. (2004). The European Union's Foreign Direct Investment into Indonesia: Determinants and Threats, in Kehal, H.S., Foreign Direct Investment in Developing Countries, Palgrave Macmillan, Ltd., USA, 134-153. https://doi.org/10.1057/9780230554412_8

Ramirez, M. D. (2000). AForeign Direct Investment in Mexico: A Cointegration Analysis. The Journal of Development Studies, 37(October), 138-162. https://doi.org/10.1080/713600062

Ros J. (1994). Financial Markets and Capital Flows in Mexico, in Ocampo, J.A., \& Steiner, R. (eds.), Foreign Capital in Latin America, Inter-American Development Bank, USA.

Theil, H. (1966). Applied Economic Forecasting. Amsterdam: North-Holland.

United Nations. (2003). World Investment Report 2003: Trends and Determinants. Switzerland: United Nations.

United Nations. (2015-2016). World Investment Report 2015-16: Trends and Determinants. Switzerland: United Nations.

Vadlamannati, K., \& A. Tamazian, (2009). Growth Effects of Foreign Direct Investment and Economic Policy Reforms in Latin America. MPRA Paper No. 14133

Weisbrot, M. (2015). Failed: What the "Experts" got wrong about the Global Economy. New York: Oxford University Press. https://doi.org/10.1093/acprof:oso/9780195170184.001.0001

Yeager, T. J. (1999). Institutions, Transition Economies, and Economic Development. Boulder: Westview Press.

Zhang, K. H. (2001). What Attracts Foreign Multinational Corporations to China? Contemporary Economic Policy, July, 336-34. https://doi.org/10.1093/cep/19.3.336

\section{Notes}

Note 1. FDI flows channeled through both Chapter XIX and DL 600 during the 1987-95 period were primarily confined to the mining sector and traditional industries such as textiles, leather, and footwear where the country $=\mathrm{s}$ has a comparative advantage based on low unit labor costs and natural resources. However, during the 1996-2002 period there was a marked decline in the proportion of FDI channeled to the mining sector and a concomitant increase in the share allocated to so-called Agreenfield sectors such as telecommunications, manufacturing, renewable energy, and financial and business services (see Alatorre and Razo, 2010; and ECLAC, 2007). This trend has also been accompanied by a change in the geographic origin of capital flows away from United States and Canadian firms and towards European (particularly Spanish) companies in the service (finance and telecommunications) sector. 
Note 2. Agosin (1995, pp. 121-122) estimates a simple regression model that tries to explain the variation in FDI flows to Chile during the 1975-93 period. He finds that both the level of real GDP in constant dollars and the real depreciation of the exchange have a positive and statistically significant effect on FDI flows. He also includes a dummy variable to capture the adoption of the debt conversion program (Chapter XIX), and finds that it also has a positive and statistically significant impact on FDI flows. The major problem with this otherwise interesting paper is that the author does not undertake a cointegration analysis of the FDI investment relationship. Given the likely presence of unit roots in the level data, the reported estimates are not reliable.

Note 3. It would be preferable to use a more direct measure of costs such as unitary labor costs. Unfortunately, data on Chilean unit labor costs for the period under review (going as far back as the sixties and early seventies) is not available in a consistent and reliable form.

Note 4. It is important not to confuse economic freedom with political and civil liberties. Countries may confer upon their citizens a substantial amount of political and civil liberty in the form of fair and competitive elections and freedom of the press, but still pursue policies that are inimical to economic freedom such as high levels of taxation and excessive government intervention and regulation.

Note 5. There are no initial estimates for the foreign capital stock in Chile in 1960 or, for that matter, its rate of depreciation. This study constructed the stock of foreign capital in Chile based on the assumption that its general trend does not differ significantly from that of the country $=$ s total fixed private capital stock. The capital growth rate and depreciation estimates were obtained from Hoffman (2000, Appendix H, p. 277). The initial private capital stock is constructed on an assumed private capital stock growth rate of 3 percent (equal to the growth rate of GDP in 1940-60) and the following estimates for depreciation: 2.5 percent for construction (40 years of service life) and 7 percent for machinery and equipment (14 years). In view of the fact that there are no disaggregated data on the composition of foreign capital flows to Chile for the period under review (viz., structures vs. machinery and equipment), this study used a 5 percent depreciation rate (20 years of service life). The latter figure is the same as that used by ECLAC (1998) in its computation of capital stocks for several major Latin American nations (including Chile, see Technical Note 2, pp. 162-165). In fact, ECLAC argues that the higher rate of depreciation is more appropriate in view of the faster obsolescence rate for machinery and equipment with a high technological content. For example, ECLAC reports that at the beginning of the 1990s computers and related equipment were depreciated in 5 years, yet by the end of the decade, they were depreciated in just two years (p. 163). Finally, Hoffman reports that the capital-output ratio for Chile was quite stable for the 1950-60 period, averaging 2.74, and for the 1957-60 period used in this study, it was unchanged at 2.7 (for further details, see Appendix H, pp. 276-278). To ensure the robustness of the econometric results, other estimates of the rate of depreciation were used (1 and 10 percent), as well as different estimates of the initial foreign capital stock (e.g., summing over 3 and 5 years), but the results were not altered significantly.

Note 6. Unit root tests under the assumption of a deterministic trend also indicated that in 


\section{Macrothink}

level form the variables were non-stationary. Thus, the common practice of de-trending the data would not render them stationary (results are available upon written request).

Note 7. The ECM model was also estimated with the growth rate in the percentage of paved roads and the results indicated that a ceteris paribus increase in the growth rate in the percentage of paved roads by 10 percent generates a 3.5 percent increase in FDI inflows $(\mathrm{t}-\mathrm{stat}=2.00$, p-value $=.052)$.

Note 8 . The length of the lags is likely to change as the legal-institutional environment for conducting business in Chile improves. In this scenario, the flow of FDI to Chile is likely to become more responsive to any future changes in GDP and/or the real exchange rate, ceteris paribus.

Note 9. EFI was also highly correlated with the LGDP variable (0.81).

\section{Copyright Disclaimer}

Copyright for this article is retained by the author(s), with first publication rights granted to the journal.

This is an open-access article distributed under the terms and conditions of the Creative Commons Attribution license (http://creativecommons.org/licenses/by/3.0/). 